\title{
MIASTENIA GRAVE INDUZIDA POR D-PENICILAMINA EM PACIENTE COM ESCLEROSE SISTEMICA PROGRESSIVA
}

\author{
PAULO E. MARCHIORI* \\ MILBERTO SCAFF"** \\ WILSON COSSERMELLI ***
}

J. LAMARTINE DE ASSIS ****

$\mathrm{O}$ desenvolvimento de doenças autoimunes em alguns pacientes tratados com D-penicilamina (DPA) com desordens na junção neuromuscular (JNM) subclínica e miastenia grave (MG) é relatado desde $1974{ }^{3,5,13}$. O emprego terapêutico da DPA, que antes de 1970 se restringia a doença de Wilson e cistinúria, estendeu-se posteriormente a doença reumatóide, esclerose sistêmica progressiva (ESP) e poliarterite nodosa, acompanhou-se de crescente aparecimento de $M G$, possivelmente devido a predisposição geral a doenças imunológicas relacionadas a DPA 2, 3, 4, 5, 6, 9, 13. A MG induzida pela DPA é similar à forma espontânea clínica, farmacológica e eletrofisiologicamente, predominando sinais oculares na primeira $3,4,11,13$; tanto o acometimento bulbar como o sistêmico, porém, podem ocorrer ${ }^{4,13}$. Em geral a manifestação miastênica ocorre 6 a 10 meses após o início DPA:2, 3, 16, 18, 14 e cerca de 90\% dos casos revelam anticorpos antirreceptor de acetilcolina ( $A C h R)$ com reatividade cruzada principalmente aos AChR humano e hiperplasia tímica ${ }^{3}$.

O objeto deste registro é apresentar um desses casos.

\section{OBSERVAÇÃO}

M.T.L., 41 anos, branca, procedente de São Paulo, acompanhada no Hospital das Clínicas da FMUSP por apresentar manchas na pele, parestesias nos dedos e fenômeno de Raynaud, desde os 13 anos, e dores poliarticulares. Houve espessamento insidioso da pele e hemiatrofia no dimídio esquerdo. Foi diagnosticada esclerose sistêmica progressiva. Foi submetida a diversas terapêuticas, sem melhora. Há um ano iniciou DPA (250 mg/dia). Seis meses após queixou-se de "visão dupla". O emprego de DPA foi mantido devido a melhora clínica. Posteriormente, semiptose palpebral bilateral, mais acentuada a direita e fraqueza nos quatro membros limitavam seus movimentos. Referia disfagia, tosse e dispnéia esporádica, há 5 anos. Nos antecedentes pessoais, queixava-se de "bronquite" há cinco anos. Exame clínico - emagrecida, pálida, pressão arterial

Trabalho realizado nas Disciplinas de Neurologia Clínica (* Médico Assistente; ** Professor Livre Docente; **** Professor Adjunto) e de Reumatologia (*** Professor Titular) dos Departamentos de Neuropsiquiatria e de Clínica Médica da Faculdade de Medicina da Universidade de São Paulo (FMUSP). 
de $170 / 110 \mathrm{mmHg}$, freqüência de pulso de $80 \mathrm{bpm}$ e freqüência respiratória de $24 \mathrm{mrm}$. Pele universalmente espessada, enrijecida e atrófica, dificultando seus movimentos. Hemiatrofia do dimídio esquerdo. Não há evidência de anormalidades cardiovasculares, respiratórias ou abdominais. Exame neurológico - consciente, cooperativa, tetraparesia proximal, mais evidente no dimídio esquerdo e amiotrofia na mão direita, diplopia ao olhar conjugado, déficit do múscrlo abducente direito, semiptose palpebral bilateral e diparesia facial. Exames laboratoriais de rotina normais; fator anti-núcleo positivo $1 / 800$, padrão homogêneo e periférico $(1 / 10)$ fator reumatóide $1 / 80$, anticorpo antinúcleo extraível (FNA) 1/40, anticorpo anti-SM 1/40 ( $\mathrm{Sm}$ ) e complemento total de 129 unidades hemolíticas/ml; raio-X de mãos: desmineralização óssea difusa, pinçamento articulares proximal e distal. Evolução - 15 dias após a descontinuação da DPA houve remissão da diplopia; porém, a semiptose palpebral e tetraparesia não melhoraram. Um mês após introduziu-se brometo de piridostigmina $90 \mathrm{mg}$ diários com evidente melhora das manifestações oculares e do déficit proximal; o déficit do músculo abd cente direito melhorou algumas semanas mais tarde.

\section{COMENTARIOS}

A patogênese da DPA-MG é obscura. As propriedades químicas da DPA permitem reação e alterações das proteinas do hospedeiro, modificações estruturais nas ligações lisina-alisina de estrutura do colágeno modificando suas propriedades antigênicas. A DPA liga-se a sub-unidades $\alpha, \beta, \gamma$ do receptor de acetilcolina. Reduz as pontes S-S na sub-unidade gama, diminui as ligações de alta afinidade, abole o sistema cooperativo e reduz as conexões S-S na sub-unidade alfa próxima à ligação da acetilcolina ao receptor ${ }^{3}$. Essa interação entre DPA-receptor de acetilcolina pode induzir alteração antigênica, produzindo o processo autoimune, com desordem da reatividade imunológica, diminuição da divisão celular das células $\mathrm{T}$, quebra da tolerância imunológica, alterações musculares inflamatórias generalizadas e anomalias na transmissão neuromuscular ${ }^{3,4}$. Outro possivel mecanismo etiopatogênico da $M G$ induzida pela DPA pode estar relacionado à estimulação da síntese da prostaglandina E-1 que ocupa sítios alostéricos do receptor de acetilcolina interferindo na transmissão neuromuscular 8. A MG desencadeada pela DPA deve melhorar em torno de dois meses após a descontinuação da droga, porém, caso persista cinco meses ou mais os anticolinesterásicos poderão ser utilizados 4, 12, 14 .

\section{RESUMO}

Relato de caso de miastenia grave induzida por D-penicilamina. São descutidos os possiveis mecanismos etiopatogênicos envolvidos no desencadeamento da doença e é salientada a presença de anticorpo anti-receptor de acetilcolina e hiperplasia tímica na DPA-MG. 


\section{SUMMARY}

\section{Myasthenia gravis induced by D-penicillamine in a progressive systemic sclerosis case.}

The development of autoimmune diseases in some patients treated with D-penicillamine (DPA) suggests that the reported occurrence of a conduction disorder at the neuromuscular junction and the development of a reversible myasthenia gravis in rheumatoid disease, progressive systemic sclerosis or Wilson's disease after the use of DPA are part of a general predisposition for autoimmune disease related to DPA therapy. The case reported is an example. The DPA- induced myasthenia gravis (MG) is similar to the spontaneous MG clinically and electrophysiologically, though ocular signs prevail in the former. Antibodies to acetylcholine receptor have been demonstrated and thymic hyperplasia also has been formed. Regarding the onset of myasthenic manifestations the duration of the treatment with DPA varies from 6 to 10 months. The action of DPA on the neuromuscular junction is different from that occurring in spontaneous MG. The pathogenesis of the DPA induced MG is still obscure. The chemical properties of DPA permit it to react with many proteins and some alteration of proteins may appear, with structural changes in the composition and antigenicity of the collagen fibers. In vitro DPA causes disorder of acetylcholine receptor bridges to $\alpha, \beta, \gamma$ sub-units with reduction of the S-S bridges in the $\gamma$-subunit. This decreases the linkage of high affinity and abolishes its positive cooperative system, reducing the S-S connection in the $\alpha$-unit near the acetylcholine linkage. The interation between DPA and receptor may induce antigenic alteration in this latter, starting the autoimmune phenomena. The other possibility is the stimulation of prostaglandin E-1 synthesis by DPA may fill the allosteric place of $\mathrm{ACh}$ receptor, interfering on the neuromuscular junction.

\section{REFERENCIAS}

1. BEHAN, P. - Immune disease and HLA association with myasthenia gravis. J. Neurol. Neurosurg. Psychiat. 43:611, 1980.

2. BEVER, C.; WONG CHANG, H.; PENN, S.A.; JAFFE, A.I. \& BOCK, E. - Chemical alteration of $\mathrm{AChR}$ by penicillamine: a mechanism for the induction of myasthenia gravis. Neurology (NY) 31:84, 1981.

3. BEVER, C.T.; WONG CHANG, H.; PENN, A.S.; JAFFE, A.I. \& BOCK, E. Penicillamine on acetylcholine receptor. Neurology (NY) 32:1077, 1982.

4. BUCKNALL, R.C.; DIXON, A.S.T.J.; GLICK, E.N.; WOOLAND, J. \& ZUTSCHI, E.W. - Myasthenia gravis associated with penicillamine treatment for rheumatoid arthritis. Brit. med. J. 1:600, 1975.

5. BURRES, S.A.; KANTER. M.E.; RICHMAN, D.P. \& ARNARON, B.G.W. - Studies on the pathophysiology of chronic D-penicillamine-induced myasthenia. Ann. N.Y. Acad. Sci. 377:640, 1981.

6. EPSTEIN, O.; De VILLIERS, D.; JAIN, S.; POTTER, B.J.; THOMAS, H.C. \& SHERLOCK, S. - Reduction of immune complexes and immunoglobulins induced by penicillamine in primary biliary cirrhosis. N. Engl. J. Med. 300:274, 1979.

7. HERBERT, C.M.; LINDBERG, K.A.; JAYSON, M.I.V. \& BELI, A.J. - Biosynthesis and maturation of skin collagen in scleroderma: the effect of D-penicillamine. Lancet 1:187-192, 1974. 
8. HORROBIN, D.F. - Myasthenia and prostaglandin E-1. Ann. int. Med. 90:719, 1979.

9. MUERS, M. \& STOKES, W. - Treatment of scleroderma heart by D-penicillamine. Brit. Heart J. 38:864, 1976.

10. MITCHEL, G.W.; LICHTENFELD, P.J. \& MCDONALD, C.J. - Myasthenia gravis and scleroderma. J. amer. med. Assoc. 233:531, 1975.

11. RUSSEL, A.S. \& LINDSTROM, J.M. - Penicillamine-induced myasthenia gravis associated with antibodies to acetylcholine receptor. Neurology (Minneapolis) 28:847, 1978.

12. STALBERG, E. - Clinical electrophysiology in myasthenia gravis. J. Neurol. Neurosurg. Psychiat. 43:622, 1980.

13. SYMPSON, J.A. - Myasthenia gravis: a personal view of pathogenesis and mechanism. Muscle Nerve 1:45, 1978.

14. TORRES, F.C.; GRIGGS, R.C.; BAUM, J. \& PENN, S.A. - Penicillamine-induced myasthenia gravis in progressive systemic sclerosis. Arthritis. Rheumat. 23:505, 1980.

Cliniaa Neurológica, Hospital das Clinicas, FMUSP - Caixa Postal 3461 - 01000, Sdo Parulo, SP - Brasil. 